\title{
Investigation of the Composition \\ of High-Viscosity and Heavy Oils in the Course of EOR-Process Simulation
}

\author{
Darya I. Chuikina ${ }^{a}$, Irina V. Russkikh*a, \\ Larisa D. Stakhina ${ }^{\mathrm{a}, \mathrm{b}}$ and Olga V. Serebrennikova ${ }^{\mathrm{a}, \mathrm{c}}$ \\ ${ }^{a}$ Institute of Petroleum Chemistry SB RAS \\ 4 Akademichesky, Tomsk, 634055, Russia \\ ${ }^{b}$ National Research Tomsk State University \\ 36 Lenin, Tomsk, 634050, Russia \\ 'National Research Tomsk Polytechnic University \\ 30 Lenin, Tomsk, 634050, Russia
}

Received 13.01.2017, received in revised form 17.04.2017, accepted 21.05.2017

The effect of Enhanced Oil Recovery (EOR) system in the laboratory on the composition of highviscosity and heavy oils from the oil fields of Russia, Germany and Mongolia was investigated. It is shown that thermal treatment and influence to the components of the EOR system causes a significant change in the composition and properties of the investigated oils. The content of low molecular weight $n$-alkanes in the treated oils was increased 2.5 times. Viscosity of oils was reduced almost three times, the amount of oxygen-containing compounds and total acid number of oils has also declined.

Keywords: oil, EOR system, asphaltenes, resins, hydrocarbons, paraffins, acids.

DOI: $10.17516 / 1998-2836-0018$.

(c) Siberian Federal University. All rights reserved

* Corresponding author E-mail address: vdi@ipc.tsc.ru, rus@ipc.tsc.ru 


\title{
Изучение состава высоковязких
}

\section{и тяжелых нефтей в процессе моделирования методов увеличения нефтеотдачи}

\author{
Д.И. Чуйкина ${ }^{a}$, И.В. Русских ${ }^{\mathrm{a}}$, \\ Л.Д. Стахина ${ }^{\mathrm{a}, \boldsymbol{\sigma}}$, О.В. Серебренникова ${ }^{\mathrm{a}, \mathrm{s}}$ \\ ${ }^{a}$ Институт химии нертии СО РАН \\ Россия, 634055, Томск, пр. Академический, 4 \\ ${ }^{6}$ Наииональный исследовательский \\ Томский государственный университет \\ Россия, 634050, Томск, пр. Ленина, 36 \\ ${ }^{8}$ Национальный исследовательский \\ Томский политехнический университет \\ Россия, 634050, Томск, пр. Ленина, 30
}

Исследовано влияние методов увеличения нефтеотдачи (МУН) пластов в лабораторных условиях на состав высоковязких и тяжелых нефтей России, Германии и Монголии. Показано, что термическая обработка и воздействие компонентов МУН вызывают значительные изменения в составе и свойствах исследованных нефтей. Содержание низкомолекулярных н-алканов в обработанной нефти увеличилось в 2.5 раза. Вязкость нефти снизилась практически в три раза, количество кислородсодержащих соединений и общее кислотное число нефти также снизились.

Ключевые слова: нефть, методы увеличения нефтеотдачи, асфальтены, смолы, углеводороды, парафины, кислоты.

\section{Introduction}

In recent years the quota of heavy and high-viscosity oils in the world's crude oil production has been increasing. The world's heavy and high-viscosity crude oils reserves exceed by about 5 times the proven low- and medium-viscosity crude reserves of Canada, Venezuela, Russia, USA, Mexico, China, Germany, Mongolia and other countries of the world [1-3].

At present thermal enhanced oil recovery is an increasingly common method of extracting heavy crude oils worldwide. Water steam is widely used as a heat carrier. The main two forms of the technology for thermal stimulation of oil reservoirs are cyclic steam simulation and steam flooding $[4,5]$. The process is repeated until production falls below a profitable level. Similar studies of steam stimulation processes have been conducted recently. The data obtained suggest that, due to the joint effect of water and heat, the physical properties of oils, e.g. viscosity, are liable to change [6]. Another idea (VAPEX) is to recover heavy oils using saturated hydrocarbon (propane, butane) vapours under carefully controlled conditions which lead to separation of asphaltenes from heavy crude. The asphaltenes thus left behind are deposited on the reservoir matrix while the much lighter oil is recovered [7]. For the evaluation of

$$
-207-
$$


heavy petroleum fractions, thermogravimetry (TG), a thermal analysis technique, is considered a good analytical tool to determine the thermal behavior of these fractions at high temperatures. TG analyses were made of petroleum distillation residues from different Brazilian oils. The apparent cracking activation energy of saturates, aromatics, resins and asphaltenes was also determined by TG [8].

Many researchers are steadily making attempts to find chemical additives to steam in order to improve its effect. Recently, there have been important progresses in oil recovery using chemical addition. At present carbon dioxide gas $\mathrm{CO}_{2}$ is considered as the best additive. The reasons of $\mathrm{CO}_{2}$ beneficial effect are well known: it increases a phase permeability of a oil reservoir, decreases oil viscosity etc. $[9,10]$. Miscible carbon dioxide $\left(\mathrm{CO}_{2}\right)$ flooding has become the most commonly and favorable approach in EOR because of its high oil reservoir sweep efficiency and contribution to the reduction of greenhouse gas emissions. The results of $\mathrm{CO}_{2}$ gas injection revealed that the amount of pure asphaltenes molecules deposition was increased to a great extent as the $\mathrm{CO}_{2}$ mole fraction was increased [11]. As well, in fields of Russia and Venezuela surfactant has been used to generate foams that enhance steam distribution more evenly in the reservoir $[12,13]$. The field tests in Henan Oil Field, China, using carbamide increased oil recovery by 7 \% [14]. During some years many researchers are developing the concept of the treatment of high-viscosity oil pool with surfactant-based systems, which due to a heat carrier generate $\mathrm{CO}_{2}$ and ammonia buffer solution in situ [15]. During a water-alternating-gas (WAG) flooding process for heavy oil reservoirs, the adverse mobility ratio leads to a considerable amount of injection gas fingering through the oil zone. To improve the recovery efficiency of the WAG process for Saskatchewan (Canada) heavy oil reservoirs, a laboratory feasibility study was conducted to evaluate an improved WAG process that augments the injection water with chemicals (alkali/surfactant/polymer) [16]. Recently, many studies have shown that the comprehensive effects of water and heat in steam stimulation processes may not only change the physical properties of heavy oils, but also produce chemical reactions $[17,18]$. Many chemical reactions include decarboxylation of oil components, formation of $\mathrm{H}_{2} \mathrm{~S}$ from sulfur in the crude, formation $\mathrm{H}_{2}, \mathrm{CO}, \mathrm{CH}_{4}$ and $\mathrm{CO}_{2}$ from reactions between water, chemical additions and crude [19]. As a result, we conducted a study in the laboratory on high-viscosity and heavy crude oils and investigated the physical properties and the component changes of oils during EOR simulation processes.

We have decided upon the given EOR systems for the following reason: these systems contain surfactants; hence, in the course of treatment they are capable to generate carbon-dioxide gas and alkaline buffer solutions in situ. As a result, oil viscosity, interfacial tension and clay swelling decrease, whereas the mobility of reservoir fluids increases, which results in an enhancement of the oil-displacement factor and in a decrease of residual oil saturation. Pilot tests were carried out in Usinskoye oil field (Russia) and Lyaohe oil field (China) [20, 21].

\section{Experimental}

Oil samples. The test samples of high-viscosity and heavy crude oils were obtained from Russian, German and Mongolian oil production factories. These are designated as R, G and M, respectively. The composition of original oils samples were determined, the results are listed in Table 1.

Method for removing water and solids from oil samples. Before analysis water and particulates should be removed from the sample by centrifugation or settling. Sample of heavy crude oil with water 
Table 1. The SARA composition of the oil samples before and after treatment

\begin{tabular}{|c|c|c|c|c|c|}
\hline \multirow{2}{*}{\multicolumn{2}{|c|}{ Oil sample }} & \multicolumn{4}{|c|}{ SARA (wt \%) } \\
\hline & & \multirow{2}{*}{$\begin{array}{c}\begin{array}{c}\text { Saturated }+ \\
\text { Aromatic HCs }\end{array} \\
78.8\end{array}$} & \multirow{2}{*}{$\begin{array}{c}\text { Resins } \\
11.5\end{array}$} & \multirow{2}{*}{$\begin{array}{c}\text { Asphaltenes } \\
9.7\end{array}$} & \multirow{2}{*}{$\begin{array}{c}\text { Paraffins } \\
0.8\end{array}$} \\
\hline & Before & & & & \\
\hline & After & 80.6 & 11.0 & 8.4 & 0.5 \\
\hline \multirow{2}{*}{$2 \mathrm{R}$} & Before & 92.5 & 6.5 & 1.0 & 15.3 \\
\hline & After & 93.8 & 4.8 & 1.4 & 10.2 \\
\hline \multirow{2}{*}{$3 \mathrm{G}$} & Before & 87.5 & 12.2 & 0.3 & 9.8 \\
\hline & After & 88.8 & 10.7 & 1.5 & 9.1 \\
\hline \multirow{2}{*}{$4 \mathrm{G}$} & Before & 88.0 & 10.4 & 1.6 & 12.4 \\
\hline & After & 88.1 & 9.6 & 1.9 & 11.6 \\
\hline \multirow{2}{*}{$5 \mathrm{M}$} & Before & 91.1 & 8.4 & 0.5 & 16.8 \\
\hline & After & 91.2 & 7.9 & 0.9 & 8.8 \\
\hline \multirow{2}{*}{$6 \mathrm{M}$} & Before & 83.5 & 15.4 & 1.1 & 14.6 \\
\hline & After & 85.3 & 13.9 & 0.8 & 7.1 \\
\hline
\end{tabular}

are placed into a cone-shaped centrifuge tube. After centrifugation the volume of the higher gravity water with sediment layer at the bottom of the tube is calculated.

Experimental procedure. A mixture of oil sample and EOR system was prepared in the volume ratio of $2: 1$; it was kept for $24 \mathrm{~h}$ in a closed autoclave at constant temperature $\left(125-200{ }^{\circ} \mathrm{C}\right)$ and pressure of 2-4 MPa, and then cooled down to room temperature. The technology for EOR was simulated by adapting the composition and temperature of EOR system to the oil reservoir conditions. The EOR systems generally contain surfactants, ammonium nitrate and carbamide, capable of producing carbon dioxide and thus create an alkaline buffer system in situ. Due to the carbamide decomposition, $\mathrm{CO}_{2}$ was isolated; in the course of its barbotage mixing of the oil phase took place. With the test completed, the oil phase was separated from the water phase containing the composition.

The simulation was performed using EOR system having optimal composition; the non-ionogenic anion-active surfactants produced in Russia and China were employed. The physical properties and the component changes of the oil samples were also determined. The influence of oil-displacement system on the rheological characteristics (viscosity) of the oil samples was studied at $20^{\circ} \mathrm{C}$; the density of the samples was examined at $15{ }^{\circ} \mathrm{C}$.

SARA composition analysis. SARA oil testing measures saturates, aromatics, resins and asphaltenes in crude oils, distillates and feed stocks. The composition of the studied oil samples was determined by liquid adsorption chromatographic (LC) analysis of the deasphalted oil. The asphaltenes were separated from the oil samples by bringing the oil into contact with dry hexane in 40-volume excess. The liquid chromatographic analysis was carried out on silica column. The silica column was activated previously with dry hexane. The saturated and aromatic fractions were obtained by elution with hexane, the resins were obtained by elution with mixture chloroform and methyl alcohol (93:7 by volume). The fractions were quantified gravimetrically after the removal of the solvent. 
Viscosimetry. The rheology of the oil samples was examined at atmospheric pressure using lowfrequency vibration viscosimetry technique; the "Reokinetika" (Russia) unit was equipped with a tuning-fork vibration sensor.

Density. Relative density (specific gravity) is the ratio of the mass of a given volume of liquid at a specific temperature to the mass of an equal volume of pure water at the same or different temperature. Both reference temperatures must be explicitly stated [ASTM D1298].

Paraffins analysis. The paraffins were quantified by standard method [GOST 11851-85. (Method A). Petroleum. Method of paraffin determination].

TAN analysis. Total Acid Number (TAN), which is defined as the number of milligrams of potassium hydroxide $(\mathrm{KOH})$ needed to neutralize the acidity in one gram of crude oil. TAN is routinely measured using a standard method based on titration with $\mathrm{KOH}$ using a potentiometer (instrument) “pH-150 M" (Belarus) [ASTM D664].

Total acid number ( $\left.\mathrm{mg} \mathrm{KOH} \mathrm{g}^{-1}\right)$ is measured according to the following formula:

$$
\mathrm{TAN}=\mathrm{M} \times \mathrm{A} \times 56,1 / \mathrm{W},
$$

where: $\mathrm{A}$ - volume of alcoholic $\mathrm{KOH}$ solution used to titrate sample to end point, (ml); $\mathrm{M}$ - concentration of alcoholic $\mathrm{KOH}$ solution, ( $\mathrm{mol} / \mathrm{ml})$; $\mathrm{W}$ - sample mass, (g).

Elemental analysis. The elemental composition of the oil samples was determined with respect to carbon, hydrogen, nitrogen, sulfur and oxygen contents, using a "Vario EL cube" unit (Elementar Analysensysteme GmbH, Germany). The sample sizes for auto sampling varied from 3.0 to $4.0 \mathrm{mg}$.

GC analysis. The individual composition of $n$-alkanes was determined by gas-liquid chromatography method on instrument "Chromos GC-1000" (Chromos, Russia). The unit equipped with a flame-ionization detector with helium employed as gas carrier; the capillary column coated with SE-54 phase had length $25 \mathrm{~m}$. Chromatograms recording was carried on at a rate of $4{ }^{\circ} \mathrm{C}$ per min with linear temperature programming from 80 to $280^{\circ} \mathrm{C}$.

\section{Results and discussion}

The effect of treatment on the viscosity of the oil samples. Five oil samples $(2 \mathrm{R}, 3 \mathrm{G}, 4 \mathrm{G}, 5 \mathrm{M}$, $6 \mathrm{M}$ ) have high paraffins content (more $6 \mathrm{wt} \%$ ), one sample (heavy oil 1R) have high resin+asphaltene content $(21.2 \mathrm{wt} \%)$. All 6 oil samples used in the experiment have high viscosity indexes 1160 $22713 \mathrm{mPa} \cdot \mathrm{s}\left(\right.$ at $\left.+20^{\circ} \mathrm{C}\right)$.

The treatment was found to cause a decrease in the viscosity of the oil samples from 33 to 96 rel \%, depending on the oil composition (see Table 2).

Thus the highest decrease in the viscosity (89-96 \% rel) was observed for the treated oil samples $2 \mathrm{R}, 5 \mathrm{M}$ and $6 \mathrm{M}$, which had the lowest asphaltenes contents (0.5-1.1 wt \%); however, the same samples had the highest paraffins contents (14.6-16.8 wt \%).

The effect of treatment on the composition of the oil samples. The SARA analysis was made using the oil samples before and after treatment; the results are listed in Table 1.

The treatment has evidently caused a decrease of $0.1-1.8 \mathrm{wt} \%$ in the total resins + asphaltenes content; at the same time, the content of saturated+aromatic HCs has increased by $0.1-1.8 \%$. The highest decrease in the paraffins content (5.1-8.0 wt \%) are observed for samples $2 \mathrm{R}, 5 \mathrm{M}$ and $6 \mathrm{M}$. 
Elemental analysis of the oils. The elemental analysis was made for studied oil samples; the results are presented in Table 3. It can be seen that the EOR system treatment has caused a decrease in the content of oxygen and only an insignificant decrease in the content of sulfur. The nitrogen content, on the contrary, has increased, which is due to the interaction of organic acids with ammonia released from the EOR system. On the other hand, a decrease in the oxygen content might be due to partial decarboxylation by heating of the composition. The EOR treatment has caused only an insignificant decrease in the density of the oil samples (see Table 3). The above results suggest that the composition of heavy and high-viscosity oils studied is affected by the EOR treatment, since EOR systems contain surfactants, ammonium nitrate and carbamide. Due to the treatment using EOR system, a thermotropic system would form.

It is capable to generate in situ a physic-chemical mechanism based on the kinetics of carbamide hydrolysis in water and EOR systems at $70-250{ }^{\circ} \mathrm{C}$ to yield ammonia and carbon dioxide [22].

Table 2. The viscosity of the oil samples before and after treatment

\begin{tabular}{|c|c|c|c|}
\hline \multirow{2}{*}{$\begin{array}{c}\text { Oil } \\
\text { sample }\end{array}$} & \multicolumn{2}{|c|}{ Dynamic viscosity, $\mathrm{mPa} \bullet \mathrm{s}\left(\right.$ at $\left.+20^{\circ} \mathrm{C}\right)$} & $\begin{array}{c}\text { Decrease in viscosity } \\
\text { (rel \%) }\end{array}$ \\
\cline { 2 - 4 } & Before treatment & After treatment & 58 \\
\hline $1 \mathrm{R}$ & 8260 & 3450 & 96 \\
\hline $2 \mathrm{R}$ & 3292 & 133 & 33 \\
\hline $3 \mathrm{G}$ & 1160 & 780 & 69 \\
\hline $4 \mathrm{G}$ & 6607 & 2050 & 91 \\
\hline $5 \mathrm{M}$ & 2244 & 190 & 89 \\
\hline $6 \mathrm{M}$ & 22713 & 2500 & 6 \\
\hline
\end{tabular}

Table 3. The effect of EOR system treatment on the elemental composition and density of the oil samples

\begin{tabular}{|c|c|c|c|c|c|c|c|}
\hline \multirow{2}{*}{\multicolumn{2}{|c|}{ Oil sample }} & \multirow{3}{*}{$\begin{array}{c}\begin{array}{c}\text { Density at } \\
+15^{\circ} \mathrm{C}, \mathrm{kg} \mathrm{m}^{-3}\end{array} \\
975\end{array}$} & \multicolumn{5}{|c|}{ Elemental composition (wt \%) } \\
\hline & & & \multirow{3}{*}{$\begin{array}{c}\mathrm{C} \\
85.48 \\
84.51\end{array}$} & \multirow{2}{*}{$\begin{array}{c}\mathrm{H} \\
10.95\end{array}$} & \multirow{2}{*}{$\begin{array}{c}\mathrm{S} \\
1.97\end{array}$} & \multirow{2}{*}{$\begin{array}{c}\mathrm{N} \\
0.64\end{array}$} & \multirow{2}{*}{$\begin{array}{c}\mathrm{O} \\
0.96\end{array}$} \\
\hline & Before & & & & & & \\
\hline & After & 974 & & 11.88 & 1.91 & 0.77 & 0.93 \\
\hline \multirow{2}{*}{$2 \mathrm{R}$} & Before & 850 & 85.06 & 11.98 & 0.01 & 0.14 & 2.81 \\
\hline & After & 844 & 85.38 & 12.54 & 0.01 & 0.30 & 1.77 \\
\hline \multirow{2}{*}{$3 \mathrm{G}$} & Before & 906 & 84.52 & 11.47 & 0.93 & 0.18 & 2.90 \\
\hline & After & 900 & 84.99 & 12.36 & 1.01 & 0.21 & 1.43 \\
\hline \multirow{2}{*}{$4 \mathrm{G}$} & Before & 858 & 84.89 & 12.26 & 0.24 & 0.16 & 2.45 \\
\hline & After & 855 & 85.80 & 12.48 & 0.22 & 0.18 & 1.32 \\
\hline \multirow{2}{*}{$5 \mathrm{M}$} & Before & 848 & 86.25 & 13.10 & 0.09 & 0.11 & 0.45 \\
\hline & After & 843 & 85.87 & 13.59 & 0.05 & 0.20 & 0.29 \\
\hline \multirow{2}{*}{$6 \mathrm{M}$} & Before & 875 & 85.75 & 12.52 & 0.01 & 0.31 & 1.41 \\
\hline & After & 870 & 86.63 & 12.68 & 0 & 0.35 & 0.34 \\
\hline
\end{tabular}


The latter component readily dissolves in water and undergoes hydrolyzation at temperatures above $70{ }^{\circ} \mathrm{C}$ in situ to give ammonia and $\mathrm{CO}_{2}$, i.e.:

$$
\mathrm{CO}\left(\mathrm{NH}_{2}\right)_{2}+\mathrm{H}_{2} \mathrm{O} \rightarrow \mathrm{CO}_{2}+2 \mathrm{NH}_{3}
$$

Carbon dioxide dissolves more readily in oil than it does in water; its distribution coefficient is in the range 4-10 for oil/water system at temperatures $70-250{ }^{\circ} \mathrm{C}$ and pressures $10-40 \mathrm{MPa}$ (cf. the respective value for ammonia $\left.\leq 6 \times 10^{-4}\right)$. Hence in the oil/water system the oil phase would be saturated with $\mathrm{CO}_{2}$ and the water phase, with ammonia. Ammonia and ammonium nitrate form a buffer system, which has maximal buffer capacity having $\mathrm{pH} 9.0-10.5$.

Thus, the effectiveness of EOR system treatment is enhanced due to the formation of carbon dioxide, which is the product of carbamide hydrolysis.

The acid content in the oil samples before and after treatment. Heavy crude oil is a complex mixture of organic compounds predominately composed of hydrocarbons, and often contains large amounts of other compounds such as organic and inorganic sulfur species, trace metals and naphthenic acids.

Naphthenic-based crudes contain a higher percentage of naphthenic acids. Naphthenic acids constitute about $50 \mathrm{wt} \%$ of the total acidic compounds in crude oils [23]. The naphthenic acids value indicates to the crude oil refinery the potential of corrosion problems. This type of corrosion is referred to as naphthenic acid corrosion (NAC). In addition, naphthenic acids may cause emulsification during the refining process, which makes it difficult to separate water from the oil and decreases the oil field $[24,25]$. The data presented in Table 4 indicates that the crude oils from Russia (samples 1R, 2R), Germany (sample 3G) are all high acidic oils with TANs above $1 \mathrm{mg} \mathrm{KOH} \mathrm{g}{ }^{-1}$, sample $4 \mathrm{G}$ from Germany is classified as acidic oil (TAN above $0.5 \mathrm{mg} \mathrm{KOH} \mathrm{g}^{-1}$ ). As is seen from Table 4, the EOR system treatment has caused a decrease in the acid number of oils, which suggests that practically all naphthenic acids have been involved in the interaction with EOR system ammonia.

Upon EOR system decomposition, the ammonia is liberated which interacts with the acids of the oil samples to give salts and amides of naphthenic acids:

$$
\begin{gathered}
\mathrm{RCOOH}+\mathrm{NH}_{3} \rightarrow \mathrm{RCOONH}_{4} \\
\text { heating } \\
\mathrm{RCOONH}_{4} \rightarrow \mathrm{RCONH}_{2}+\mathrm{H}_{2} \mathrm{O}
\end{gathered}
$$

Table 4. The acid content in the oil samples before and after treatment

\begin{tabular}{|c|c|c|c|}
\hline \multirow{2}{*}{ Oil sample } & \multicolumn{2}{|c|}{ Acid number, $\mathrm{mg} \mathrm{KOH} \mathrm{g}^{-1}$} & $\begin{array}{c}\text { Decrease in acid number, } \\
\text { rel } \%\end{array}$ \\
\cline { 2 - 3 } & Before treatment & After treatment & 79.3 \\
1R & 4.50 & 1.08 & 95.5 \\
2R & 2.42 & 0.11 & 100.0 \\
$4 \mathrm{G}$ & 4.16 & none & 100.0 \\
\hline
\end{tabular}



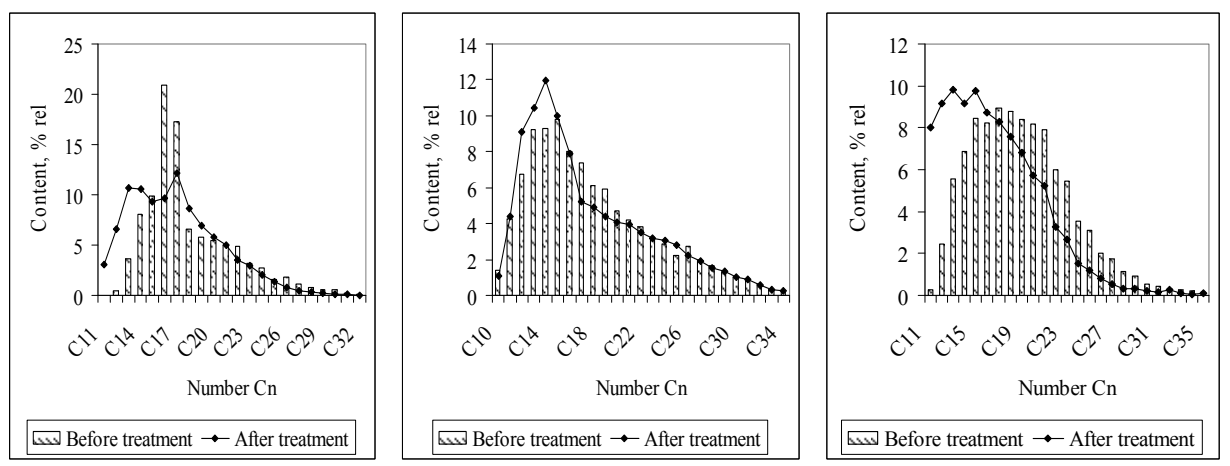

Fig. 1. The content and distribution of $n$-alkanes in oils before and after treatment: (a) sample 2R; (b) sample 4G; (c) sample $6 \mathrm{M}$

The salts of naphthenic (carboxylic) acids with ammonia and amides possess surfactant properties; therefore, they are used as demulsifiers, dispersant and detergent additives [25].

The effect of EOR system treatment on the composition of $\mathbf{n}$-alkanes in the oils. The analysis of $n$-alkanes was performed using gas-chromatography technique. The results are presented in Fig. 1. It is found that the hydrocarbons $\mathrm{C}_{10}-\mathrm{C}_{36}$ occur among the normal alkanes of the original and treated oil samples.

The results presented in Fig. 1 suggest that the treatment of the original oil using EOR systems on the base of surfactant has caused no significant change in the content and distribution of light and heavy $n$-alkanes. As a result of treatment, the fraction of light $\mathrm{HCs}_{10}-\mathrm{C}_{15}$ among the alkanes increased. The heat treatment caused an increase in the total carbon numbers less than $\mathrm{C}_{20}$ from $13-21$ to $38-53$ rel \%. A choice of chemical method, in particular, emulsion flooding, plays an important role. Thus the effectiveness of EOR technique depends on whether it makes possible reduction of the interfacial tension between oil and water by a large margin. Crude oil and EOR compositions which are solutions of surfactants, urea in water to form oil/water oil-in-water emulsions by mixing.

The results obtained in investigations suggest that oil/water emulsions prepared from long-chain alkanes are more stable than those made from short-chain alkanes [26]. The destruction of emulsions will cause the short-chain (light) alkanes to pass into crude oil, while the stable long-chain (heavy) alkanes will remain at the interface, with a resultant increase in the proportion of light alkanes in the oil phase. As a result there was a reduction in viscosity and density of the oil samples after treatment compositions.

\section{Conclusions}

1. The study on composition changes of high-viscosity and heavy oils indicate that after treatment the content of saturated and aromatic hydrocarbons in samples of oil increases and the amount of resins and asphaltenes is reduced.

2. The effect of EOR treatment and heating caused an increase from $13-21$ to $38-53$ rel $\%$ in the fraction of low-boiling hydrocarbons $\mathrm{C}_{10}-\mathrm{C}_{15}$ with the distribution of $\mathrm{C}_{10}-\mathrm{C}_{34} n$-alkanes remaining the same. 
3. It is found that the viscosity of oil samples decreased by 33 to 96 rel $\%$.

4. The content of oxygen compounds and total acid number for the treated oil samples has also decreased.

\section{Acknowledgements}

This study was supported by the Federal Science Researches program of State academies of Russia Sciences (Project No. 0370-2014-0002). Ms. Tatiana Petrenko, Ms. Tatiana Nikolaeva and Ms. Zoya Rojenkova are thanked for support in analytical measurements (Elemental, GC, density and viscosity analysis).

\section{References}

1. Hein Frances J. Heavy Oil and Oil (Tar) Sands in North America: An Overview \& Summary of Contributions. Natural Resources Research 2006. Vol. 15 (2), P. 67-84.

2. Maksutov R., Orlov G. and Osipov A. Development of High-viscosity Oil Reserves in Russia. Tekhnologii TEK 2005. No. 6, P. 46-58.

3. Meyer R.F., Attanasi E.D., Freeman Ph.A. Heavy Oil and Natural Bitumen Resources in Geological Basins of the World. US Geological Survey. Open-File Report. Reston. Virginia 2007. $42 \mathrm{p}$.

4. Donaldson E.C., Chilingarian G.V., Yen T.F. Enhanced Oil Recovery, II. Processes and Operations. Elsevier. Amsterdam, Oxford, New York, Tokyo. 1989. 594 p.

5. Santos R.G., Loh W., Bannwart A.C., Trevisan O.V. An overview of heavy oil properties and its recovery and transportation methods. Brazilian Journal of Chemical Engineering 2014. Vol. 31 (3), P. 571-590.

6. Pahlavan H., Rafiqul I. Laboratory simulation of geochemical changes of heavy crude oils during thermal oil recovery. Journal of Petroleum Science and Engineering 1985. Vol. 12, P. 219-231.

7. Butler R.M., Mokrys I.J. A new process (VAPEX) for recovering heavy oils using hot water and hydrocarbon vapour. Journal of Canadian Petroleum Technology 1991. Vol. 30 (1), P. 97-106.

8. Goncalves M.L.A., Mota D.A., Cerqueira W.V., Andre D., Saraiva L.M., Coelho M.I., Teixeira A.M., Teixeira M.A. Knowledge of petroleum heavy residue potential as feedstock in refining process using thermogravimetry. Fuel Processing Technology 2010. Vol. 91(9), P. 983-987.

9. Patent No. 4.609.043 USA. Cullick A.S. Enchanced oil recovery using carbon dioxide. Publ. 1986.

10. Sheng J. Modern Chemical Enhanced Oil Recovery. Theory and practice. Gulf Professional Publishing, Elsevier, 2011. 632 p.

11. Zanganeh P., Dashti H., Ayatollahi S. Visual investigation and modeling of asphaltene precipitation and deposition during $\mathrm{CO}_{2}$ miscible injection into oil reservoirs. Fuel 2015. Vol. 160, P. 132-139.

12. Altunina L.K., Kuvshinov V.A. Enhanced Oil Recovery with Surfactant systems. Novosibirsk: Nauka, 1995. 198 p.

13. Valera C.A., Escobar M.A., Iturbe Y.J. Use of Surfactants in Cyclic Steam Injection in Bachaquero-01 Reservoir. 1999. SPE 54020-MS. 
14. Zhang X., Zhang Y. et. al. Conformance Control of CSS and Steam Drive Process with a Carbamide Surfactant. Journal of Canadian Petroleum Technology 2009. Vol. 48 (9), P. 16-18.

15. Thomas S., Farouq Ali SM. Status and Assessment of Chemical Oil Recovery Methods. Energy Sources 1999. Vol. 21, P. 177-189.

16. Peng Luo, Yiping Zhang, Sam Huang. A promising chemical-augmented WAG process for enhanced heavy oil recovery. Fuel 2013. Vol. 104, P. 333-341.

17. Johannes Alvarez, Sungyun Han. Current Overview of Cyclic Steam Injection Process. Journal of Petroleum Science Research 2013. Vol. 2, P. 116-126.

18. Altunina L.K., Kuvshinov V.A., Stasyeva L.A. Effect of in situ generated $\mathrm{CO}_{2}$ and alkaline buffers on rheological properties of high viscosity oils. Progress Mining and Oilfield Chemistry 2003. Vol. 5, P. 123-132.

19. Fan H., Liu Y., Zhang L., Zhao X. The Study on Composition Changes of Heavy oils during Steam Simulation Processes. Fuel 2002. Vol. 81, P. 1733-1738.

20. Sherstyuk S.N., Serebrennikova O.V., Stakhina L.D., Kadichagov P.B. The Effect of EOR technologies on the composition of recovered crude oil. Journal of Siberian Federal University. Chemistry 2010. No. 3, P. 110-119.

21. Chuikina D.I., Serebrennikova O.V., Stakhina L.D., Nikolaeva T.L., Russkikh I.V. Laboratory Simulation of the Effect Oil-Displacement systems on the composition and properties of High-Paraffin Crude Oil. Journal of Siberian Federal University. Chemistry 2011. No. 1, P. 11-17.

22. Altunina L.K., Kuvshinov V.A., Kuvshinov I.V. Nanostructured systems for enhanced oil recovery. AIP Conference Proceedings 2015. Vol. 1683. 020004. http://dx.doi.org/10.1063/1.4932694

23. Tomczyk N.A., Winans R.E., Shinn J.H., Robinson R.C. On the nature and origin of acidic species in petroleum. 1. Detailed acidic type distribution in a California crude oil. Energy and Fuels 2001. Vol. 15(6), P. 1498-1504.

24. Tebbal S. Predict naphthenic acid corrosion. Hydrocarbon Engineering 2000. No. 14, P. $217-$ 223.

25. McKay J.F., Cogswell T.E., Weber J.H., Latham DeWR. Analysis of acids in high-boiling petroleum distillates. Fuel 1975. Vol. 54 (1), P. 50-61.

26. Buscall R., Davis S.S., Potts D.S. The effect of long-chain alkanes on the stability of oil-inwater emulsions. The significance of Ostwald ripening. Colloid and Polymer Science 1979. Vol. 257 (6), P. 636-644. 